\title{
Molecular detection of vector-borne bacteria in bat ticks (Acari: Ixodidae, Argasidae) from eight countries of the Old and New Worlds
}

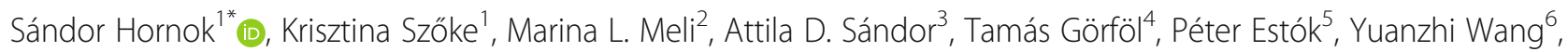
Vuong Tan Tu', Dávid Kováts ${ }^{8}$, Sándor A. Boldogh ${ }^{9}$, Alexandra Corduneanu ${ }^{3}$, Kinga M. Sulyok ${ }^{10}$,

Miklós Gyuranecz ${ }^{10}$, Jenő Kontschán ${ }^{11}$, Nóra Takács ${ }^{1}$, Ali Halajian ${ }^{12}$, Sara Epis ${ }^{13}$ and Regina Hofmann-Lehmann ${ }^{2}$

\begin{abstract}
Background: Despite the increasingly recognized eco-epidemiological significance of bats, data from molecular analyses of vector-borne bacteria in bat ectoparasites are lacking from several regions of the Old and New Worlds.

Methods: During this study, six species of ticks (630 specimens) were collected from bats in Hungary, Romania, Italy, Kenya, South Africa, China, Vietnam and Mexico. DNA was extracted from these ticks and analyzed for vectorborne bacteria with real-time PCRs (screening), as well as conventional PCRs and sequencing (for pathogen identification), based on the amplification of various genetic markers.

Results: In the screening assays, Rickettsia DNA was only detected in bat soft ticks, whereas Anaplasma phagocytophilum and haemoplasma DNA were present exclusively in hard ticks. Bartonella DNA was significantly more frequently amplified from hard ticks than from soft ticks of bats. In addition to Rickettsia helvetica detected by a species-specific PCR, sequencing identified four Rickettsia species in soft ticks, including a Rickettsia africae-like genotype (in association with a bat species, which is not known to migrate to Africa), three haemotropic Mycoplasma genotypes in Ixodes simplex, and Bartonella genotypes in I. ariadnae and I. vespertilionis.

Conclusions: Rickettsiae (from both the spotted fever and the $R$. felis groups) appear to be associated with soft rather than hard ticks of bats, as opposed to bartonellae. Two tick-borne zoonotic pathogens ( $R$. helvetica and $A$. phagocytophilum) have been detected for the first time in bat ticks. The present findings add Asia (China) to the geographical range of $R$. lusitaniae, as well as indicate the occurrence of $R$. hoogstraalii in South Africa. This is also the first molecular evidence for the autochthonous occurrence of a $R$. africae-like genotype in Europe. Bat haemoplasmas, which are closely related to haemoplasmas previously identified in bats in Spain and to "Candidatus Mycoplasma haemohominis", are reported here for the first time from Central Europe and from any bat tick.
\end{abstract}

Keywords: Chiroptera, Soft tick, Hard tick, Rickettsia, Anaplasma, Bartonella, Haemoplasma

\footnotetext{
* Correspondence: hornok.sandor@univet.hu

'Department of Parasitology and Zoology, University of Veterinary Medicine,

Budapest, Hungary

Full list of author information is available at the end of the article
}

(c) The Author(s). 2019 Open Access This article is distributed under the terms of the Creative Commons Attribution 4.0 International License (http://creativecommons.org/licenses/by/4.0/), which permits unrestricted use, distribution, and reproduction in any medium, provided you give appropriate credit to the original author(s) and the source, provide a link to the Creative Commons license, and indicate if changes were made. The Creative Commons Public Domain Dedication waiver (http://creativecommons.org/publicdomain/zero/1.0/) applies to the data made available in this article, unless otherwise stated. 


\section{Background}

Bats (order Chiroptera) are the only mammals which actively fly. Among the consequences of this trait, bats show a geographically widespread distribution and may even undergo short to long distance seasonal migration [1]. Additionally, the evolution of flight in bats yielded inadvertent consequences on their immune functioning, and therefore bats are special in their capacity to act as reservoir hosts for intracellular pathogens [2]. Bats frequently reach high population densities in or near urban habitats, and their ticks may blood-feed on humans [3, 4], which further increases their veterinary-medical importance.

The presence of DNA from vector-borne bacteria in bat ticks appears to be most extensively studied in Europe. In western Europe, Rickettsia and Ehrlichia species have been molecularly identified in soft ticks (Argas vespertilionis) of bats (in France [5] and the UK [6]). Another study carried out in central Europe (Poland) failed to detect Borrelia burgdorferi (s.l.), rickettsiae and Anaplasma phagocytophilum in the bat-associated hard tick species, Ixodes vespertilionis [7]. Nonetheless, literature data on molecular analyses of vector-borne bacteria in bat ticks are lacking from several regions of the Old and New Worlds. Therefore, during this study, bat ticks collected in countries representing less-studied regions (eastern and southern Europe, central and southeast Asia, eastern Africa, central America) were screened for the presence of DNA from four important genera of vector-borne bacteria, which include zoonotic species.

\section{Methods}

DNA extracts of 307 hard ticks (I. ariadnae: 26 larvae, 14 nymphs, 5 females; I. vespertilionis: 89 larvae, 27 nymphs, 8 females; I. simplex: 79 larvae, 50 nymphs, 9 females) and 323 soft ticks (A. vespertilionis: 321 larvae; A. transgariepinus: 1 larva; Ornithodoros sp.: 1 larva) were used. The hard ticks (Acari: Ixodidae) were collected from 200 individuals of 17 bat species in two countries (Hungary, Romania), whereas soft ticks (Acari: Argasidae) were removed from 59 individuals of 17 bat species in eight countries (Hungary, Romania, Italy, Kenya, South Africa, China, Vietnam and Mexico) [8, 9]. The geographical coordinates and/or locations of collection sites, along with identification of bat and tick species by expert taxonomists (authoring this study), have already been reported [8,9]. DNA was extracted individually from hard ticks, and individually or in pools of 2-3 specimens (if collected from the same host individual) from soft ticks, as reported $[8,9]$.

Bat tick DNA extracts $(n=514)$ were screened for the presence of Rickettsia helvetica, other Rickettsia spp., A. phagocytophilum, haemotropic Mycoplasma spp. and Bartonella spp. with real-time PCRs (Additional file 1: Table S1). This was followed by conventional PCRs and sequencing of various genetic markers (Additional file 2: Table S2), and phylogenetic analyses (Additional file 3: Text S1) except for $R$. helvetica and A. phagocytophilum.

Prevalences were compared with Fisher's exact test.

\section{Results and discussion}

Rickettsia DNA was only detected in bat soft ticks (all three evaluated species), whereas Anaplasma phagocytophilum and three haemotropic Mycoplasma genotypes were present exclusively in the hard tick species $I$. simplex (Table 1). In addition, Bartonella DNA was

Table 1 Prevalence of pathogen DNA in bat ticks according to bat host species and country of origin. The latter are referred to with superscript letters (the cumulative number of bat individuals is equal to or less than the number of positives, because one or more ticks could have been collected from a single bat). After the name of the tick species, the number of analyzed DNA extracts is shown, which corresponds to the number of tick individuals (except for A. vespertilionis, in the case of which pooled samples were also used)

\begin{tabular}{|c|c|c|c|c|c|c|}
\hline & \multicolumn{3}{|l|}{ Soft ticks } & \multicolumn{3}{|l|}{ Hard ticks } \\
\hline & $\begin{array}{l}\text { A. vespertilionis } \\
(n=205)\end{array}$ & $\begin{array}{l}\text { A. transgariepinus } \\
(n=1)\end{array}$ & $\begin{array}{l}\text { Ornithodoros sp. } \\
(n=1)\end{array}$ & $\begin{array}{l}\text { 1. vespertilionis } \\
(n=124)\end{array}$ & $\begin{array}{l}\text { 1. ariadnae } \\
(n=45)\end{array}$ & $\begin{array}{l}\text { I. simplex } \\
(n=138)\end{array}$ \\
\hline Rickettsia spp. & $120^{\mathrm{a}} / 205(58.5 \%)$ & $1^{b} / 1(100 \%)$ & $1 \% / 1(100 \%)$ & - & - & - \\
\hline Anaplasma phagocytophilum & - & - & - & - & - & $2^{d} / 138(1.4 \%)$ \\
\hline Bartonella spp. & $2 \mathrm{e} / 205(1 \%)$ & - & - & $5^{f} / 124(4 \%)$ & $5^{9} / 45(11.1 \%)$ & $6^{h} / 138(4.3 \%)$ \\
\hline Haemoplasmas & - & - & - & - & - & $1^{i} / 138(0.7 \%)$ \\
\hline
\end{tabular}

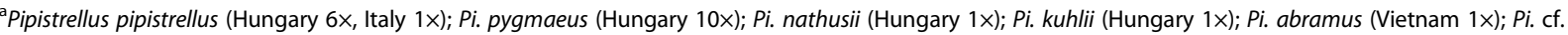
rueppellii (Kenya 1X); Myotis brandtii (Hungary 1X); My. alcathoe (Hungary 2x); My. dasycneme (Hungary 5X); Plecotus auritus (Hungary 1X); Pl. austriacus (Hungary $3 \times$ ); Nyctalus noctula (Hungary $1 \times$ ); Eptesicus serotinus (Hungary $1 \times$, Romania $1 \times$ ); Vespertilio murinus (Hungary $2 \times, C h i n a ~ 1 \times)$ ${ }^{b}$ Pi. hesperidus (South Africa $1 \times$ )

'Balantiopteryx plicata (Mexico $1 \times$ )

${ }^{\mathrm{d}}$ Miniopterus schreibersii (Hungary $1 \times$, Romania $1 \times$ )

${ }^{\mathrm{e}}$ Pi. pygmaeus (Hungary $2 \times$ )

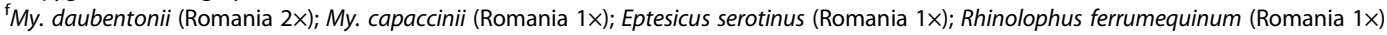

${ }^{9}$ My. alcathoe (Hungary 1X); My. bechsteinii (Hungary $1 \times$ ); My. daubentonii (Hungary $3 \times$ )

hMi. schreibersii (Romania $5 \times$ )

'Mi. schreibersii (Hungary $1 \times$ ) 
significantly more frequently detected in hard than in soft ticks of bats (Fisher's exact test: $P=0.01$ ).

In particular, $R$. helvetica was identified in one soft tick (A. vespertilionis) from China. This finding is consistent with former reports of $R$. helvetica in bat fleas [10] and bat faeces [11] in Hungary. Taking into account the bat host-specificity of these PCR-positive ectoparasites, it is possible that bats are susceptible to $R$. helvetica, although based on the very low prevalence this may have low epidemiological significance.

In four samples of $A$. vespertilionis from Hungary, the same Rickettsia genotype was identified, which was reported from bat soft ticks collected in France (GenBank: JN038177, see Table 2) [12]. More importantly, in one $A$. vespertilionis from Hungary rickettsial DNA was detected, which in the amplified part of the gltA gene had 99.9-100\% sequence identity (depending on the nucleotide at position 679: $\mathrm{C}$ or $\mathrm{T}$ ) to sequences of $R$. africae from Ethiopia (GenBank: CP001612) and from migratory bird fleas reported in neighboring Slovakia (GenBank: HM538186) [13]. Two other markers were also successfully amplified from this sample: the $17 \mathrm{kDa}$ gene sequence was identical with that of several Rickettsia species, whereas the OmpA sequence showed 2 bp differences from that of $R$. africae (Table 2).

Interestingly, the OmpA sequence from this $A$. vespertilionis was identical with that of the Rickettsia strain "Atlantic rainforest" (GenBank: MF536975 [14]) and Rickettsia sp. "Atlantic rainforest Aa46" (GenBank: KY113110 [15]), which represent a genetic variant of the human pathogen $R$. parkeri $[14,15]$ detected so far only in the New World. Nevertheless, we consider the species detected in $A$. vespertilionis to belong to $R$. africae because of the following four reasons: (i) the gltA gene is a reliable genetic marker for species identification and phylogenetic comparison of rickettsiae $[13,16]$; (ii) $R$. africae was identified based on this gene in previous studies (e.g. [13]); (iii) the gltA phylogenetic analysis confirmed that the rickettsial genotype from $A$. vespertilionis collected in Hungary clustered with $R$. africae, but apart from $R$. parkeri (Fig. 1); and (iv) the OmpA gene of the type strain of $R$. parkeri (GenBank: U43802) was only $98.3 \%$ (469/477 bp) identical with the OmpA sequence obtained here.

The soft tick containing the $R$. africae-like DNA was collected from Myotis dasycneme, which occurs north of the Mediterranean Basin and is a facultative, middle distance migrant bat species, not known to move between Europe and Africa [1]. Therefore, this result implies the autochthonous occurrence of a $R$. africae-like genotype in Europe. In the phylogenetic analysis, this genotype was clearly separated (with moderate, $72 \%$ bootstrap support value) from the Rickettsia sp. from A. vespertilionis reported in France (Fig. 1).
In addition, $R$. hoogstraalii was identified in a soft tick from South Africa (Table 2). This rickettsia has only been reported from Europe and North America [17], therefore its occurrence in Africa is new. Similarly, $R$. lusitaniae was formerly only reported in Europe (Portugal) [18] and Central America (Mexico) [19], the latter being confirmed in the present study (Table 2). However, a gltA genotype highly similar to $R$. lusitaniae (1 bp difference from JQ771933, i.e. 99.9\% identity) was also shown here, for the first time, to occur in Asia (China) (Table 2). The level of OmpA sequence divergence of this Chinese isolate (MH383149) was the same (3 bp) from $R$. lusitaniae in Portugal (JQ771935) and from R. lusitaniae in Mexico (GenBank: KX377432).

In summary, bat soft ticks contained the DNA of three Rickettsia species from the spotted fever group (SFG), and two further ones from the Rickettsia felis group (RFG) (Fig. 1).

Anaplasma phagocytophilum DNA was detected here in the hard tick species, I. simplex, in both Hungary and Romania. Previously, Anaplasma sp. DNA was also shown to be present in bat feces in Hungary (GenBank: KP862895). This low prevalence in bat ticks, suggests that bats may be susceptible to this pathogen, but most likely play a subordinate (if any) role in the epidemiology of granulocytic anaplasmosis in the evaluated region.

Bartonellae associated with bat ectoparasites, including ticks, have been reported for the first time in Hungary [10]. Based on high Ct values of the majority of bartonella-positive samples here, sequencing was only possible from two hard ticks (one I. ariadnae and one I. vespertilionis; Table 2). Based on two genetic markers (gltA and ITS), Bartonella sp. "Ia23" from I. ariadnae was relatively (Table 2: 98.2-98.7\%) similar to Bartonella sp. isolates detected in bats (My. emarginatus) in Georgia, Caucasus [20, 21]. In I. vespertilionis, known to feed on humans [3], Bartonella sp. "Iv76" was shown to be present (Table 2). The gltA sequence of this genotype was $100 \%(317 / 317 \mathrm{bp})$ identical to "Candidatus Bartonella hemsundetiensis", reported from Finland [22] (GenBank: KR822802, Table 2), but only 99.7\% (316/317 bp) identical to Bartonella sp. isolates (GenBank: KX300127, KX300131, KX300136) detected in bats (My. blythii) in Georgia, Caucasus [20]. The ITS sequence of Bartonella sp. "Iv76" was 95.1\% (291/306 bp) and 93.8\% (287/306 bp) identical to Bartonella sp. isolates (GenBank: MF288124 and KX420717, respectively) from bats (My. blythii and My. emarginatus, respectively) sampled in Georgia, Caucasus [21]. The fts $Z$ sequence similarity of Bartonella sp. "Iv76" (GenBank: MH544204) to bat-associated bartonellae available on GenBank from Georgia [20] was below 85.5\% (data not shown).

In Europe, molecular evidence on the occurrence of bat haemoplasmas has hitherto been reported from western 
Table 2 Results of molecular analyses and sequence comparisons. Species names of rickettsiae are based on highest sequence similarities to gltA sequences available on GenBank and published in peer-reviewed papers

\begin{tabular}{|c|c|c|c|c|c|}
\hline Genotype/species & $\begin{array}{l}\text { Country (no. of } \\
\text { positive samples) }\end{array}$ & $\begin{array}{l}\text { Highest sequence similarity } \\
\text { in GenBank shown as gene: bp/bp (\%) }\end{array}$ & $\begin{array}{l}\text { Closest match sequence } \\
\text { accession number }\end{array}$ & $\begin{array}{l}\text { Accession number } \\
\text { (this study) }\end{array}$ & Reference \\
\hline Rickettsia helvetica & China (1) & - & - & - & - \\
\hline \multirow[t]{3}{*}{ Rickettsia sp. Av22 } & \multirow[t]{3}{*}{ Hungary (4) } & gltA: 757/757 (100) & JN038177 & MH383138 & $\begin{array}{l}\text { Socolovschi } \\
\text { et al. [5] }\end{array}$ \\
\hline & & 17 kDa: 394/394 (100) & several & MH383143 & - \\
\hline & & OmpA: 477/477 (100) & several & MH383147 & - \\
\hline \multirow[t]{3}{*}{ Rickettsia africae-like } & \multirow[t]{3}{*}{ Hungary (1) } & gltA: 757/757 (100) & СР001612 & MH383139 & $\begin{array}{l}\text { Sekeyová } \\
\text { et al. [12] }\end{array}$ \\
\hline & & 17 kDa: 394/394 (100) & several & MH383144 & - \\
\hline & & OmpA: 475/477 (99.6) & СР001612 & MH383148 & $\begin{array}{l}\text { Sekeyová } \\
\text { et al. [12] }\end{array}$ \\
\hline \multirow[t]{2}{*}{ Rickettsia hoogstraalii } & \multirow[t]{2}{*}{ South Africa (1) } & gltA: 757/757 (100) & FJ767737 & MH383140 & $\begin{array}{l}\text { Duh et al. } \\
{[17]}\end{array}$ \\
\hline & & $17 \mathrm{kDa}: 390 / 390(100)^{\mathrm{a}}$ & FJ767736 & MH383145 & $\begin{array}{l}\text { Duh et al. } \\
{[17]}\end{array}$ \\
\hline \multirow[t]{4}{*}{ Rickettsia lusitaniae } & Mexico (1) & gltA: $757 / 757(100)^{b}$ & JQ771933 & MH383141 & $\begin{array}{l}\text { Milhano } \\
\text { et al. [18] }\end{array}$ \\
\hline & \multirow[t]{3}{*}{ China (2) } & gltA: 756/757 (99.9) & JQ771933 & MH383142 & $\begin{array}{l}\text { Milhano } \\
\text { et al. [18] }\end{array}$ \\
\hline & & 17 kDa: 393/394 (99.7) & JQ771934 & MH383146 & $\begin{array}{l}\text { Milhano } \\
\text { et al. [18] }\end{array}$ \\
\hline & & OmpA: 461/464 (99.4) & JQ771935 & MH383149 & $\begin{array}{l}\text { Milhano } \\
\text { et al. [18] }\end{array}$ \\
\hline \multirow{2}{*}{$\begin{array}{l}\text { Anaplasma } \\
\text { phagocytophilum }\end{array}$} & Hungary (1) & - & - & - & - \\
\hline & Romania (1) & - & - & - & - \\
\hline \multirow[t]{2}{*}{ Bartonella sp. la23 } & \multirow[t]{2}{*}{ Hungary (1) } & gltA: 313/317 (98.7) & KX300154 & MH544201 & $\begin{array}{l}\text { Urushadze } \\
\text { et al. [20] }\end{array}$ \\
\hline & & ITS: 520/529 (98.3) & MF288126 & MH544202 & $\begin{array}{l}\text { McKee } \\
\text { et al. [21] }\end{array}$ \\
\hline \multirow[t]{2}{*}{ Bartonella sp. Iv76 } & \multirow[t]{2}{*}{ Romania (1) } & gltA: 317/317 (100) & KR822802 & MH578453 & $\begin{array}{l}\text { Lilley } \\
\text { et al. [22] }\end{array}$ \\
\hline & & ITS: 291/306 (95.1) & MF288124 & MH544203 & $\begin{array}{l}\text { Mckee } \\
\text { et al. [21] }\end{array}$ \\
\hline Mycoplasma sp. Is128-1 & Hungary (1) & 16S rRNA: 953/954 (99.9) & KM538692 & MH383150 & $\begin{array}{l}\text { Millán } \\
\text { et al. [23] }\end{array}$ \\
\hline Mycoplasma sp. Is128-2 & Hungary (1) & 16S rRNA: 824/826 (99.8) & KM538698 & MH383151 & $\begin{array}{l}\text { Millán } \\
\text { et al. [23] }\end{array}$ \\
\hline Mycoplasma sp. Is128-3 & Hungary (1) & 16S rRNA: 952/954 (99.8) & KM538692 & MH383152 & $\begin{array}{l}\text { Millán } \\
\text { et al. [23] }\end{array}$ \\
\hline
\end{tabular}

Rickettsia helvetica and Anaplasma phagocytophilum were detected by using species-specific primers (Additional file 1: Table S1) and sequencing was not possible due to high $\mathrm{Ct}$ values

${ }^{a}$ Amplification of OmpA gene was not successful

${ }^{\mathrm{b}}$ Amplifications of $17 \mathrm{kDa}$ and OmpA genes were not successful

${ }^{c}$ Amplification of the $f t s Z$ gene was not successful

countries, i.e. Spain [23] and the Netherlands [11]. Based on blood and fecal samples, respectively, these studies suggested infections of bats with the relevant agents. Haemoplasmas are regarded as predominantly vector-borne [24]. However, bat-associated haemoplasmas have not hitherto been identified in blood-sucking arthropods. Here, three haemotropic Mycoplasma genotypes have been detected in a tick specimen (I. simplex), collected in Hungary (Table 2). Ixodes simplex is specialized to its host, Miniopterus schreibersii [25], from which bat species haemoplasma genotypes having 99.8-99.9\% $16 \mathrm{~S}$ rRNA gene similarity to those from I. simplex collected in Hungary (Table 2) have been reported in Spain [23]. Importantly, these bat-associated haemoplasmas are phylogenetically 


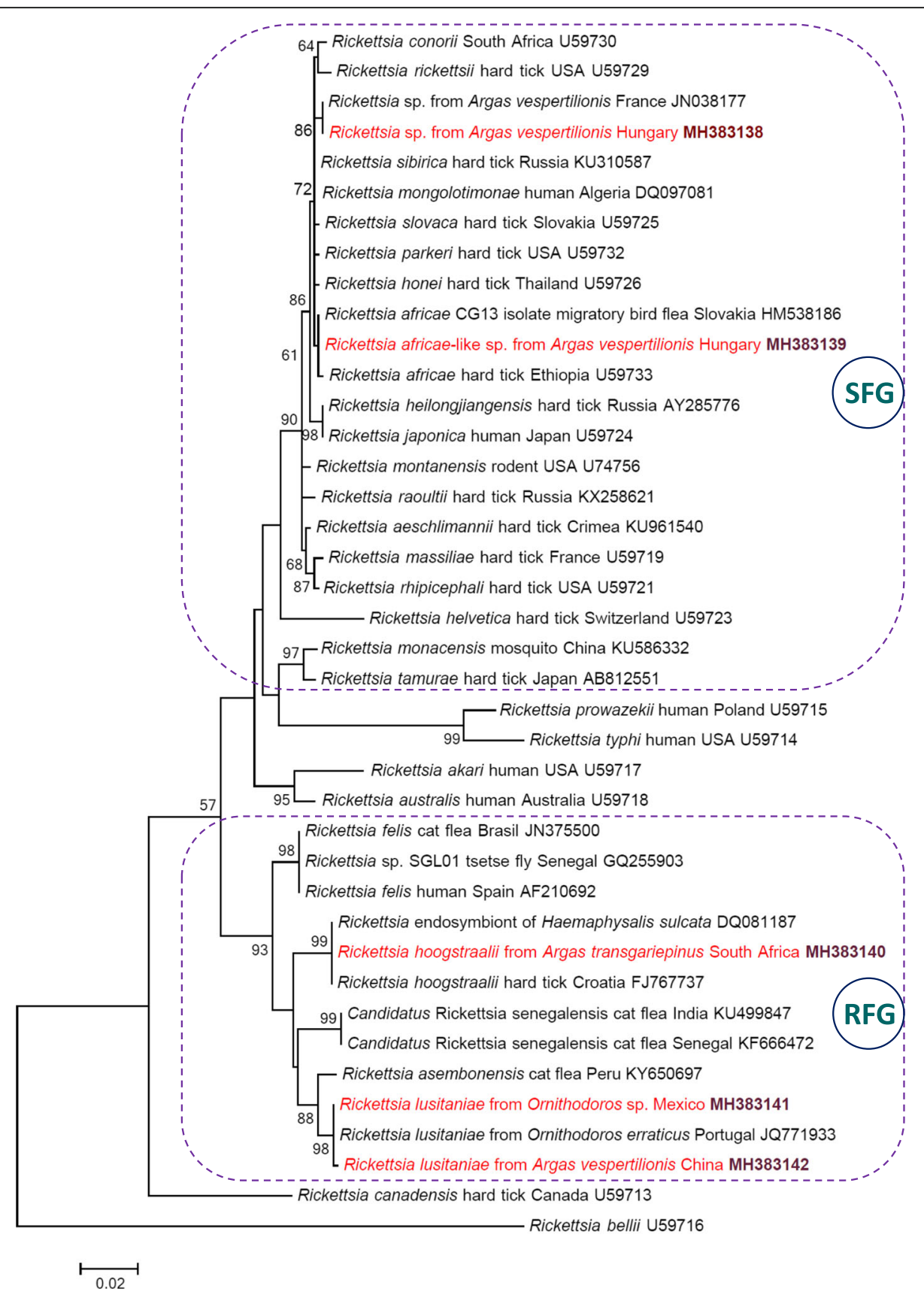

Fig. 1 Maximum-likelihood tree of spotted fever group (SFG: encircled with dashed line), Rickettsia felis group (RFG: encircled with dashed line) and other rickettsiae based on the gltA gene. Sequences from this study are highlighted with red color and bold accession numbers. Branch lengths represent the number of substitutions per site inferred according to the scale shown

close to "Candidatus Mycoplasma haemohominis", as reported [23] and as also shown here (Fig. 2).

\section{Conclusions}

Rickettsiae (from both the spotted fever and the R. felis groups) appear to be associated with soft rather than hard ticks of bats, as opposed to bartonellae. Although with low prevalence, two tick-borne zoonotic pathogens
( $R$. helvetica and $A$. phagocytophilum) have been detected for the first time in bat ticks. The present findings add Asia (China) to the geographical range of $R$. lusitaniae, as well as indicate the occurrence of $R$. hoogstraalii in South Africa. This is also the first molecular evidence of a $R$. africae-like genotype in Europe, in association with a bat host species that is not known to migrate to Africa. Bat haemoplasmas, which are 


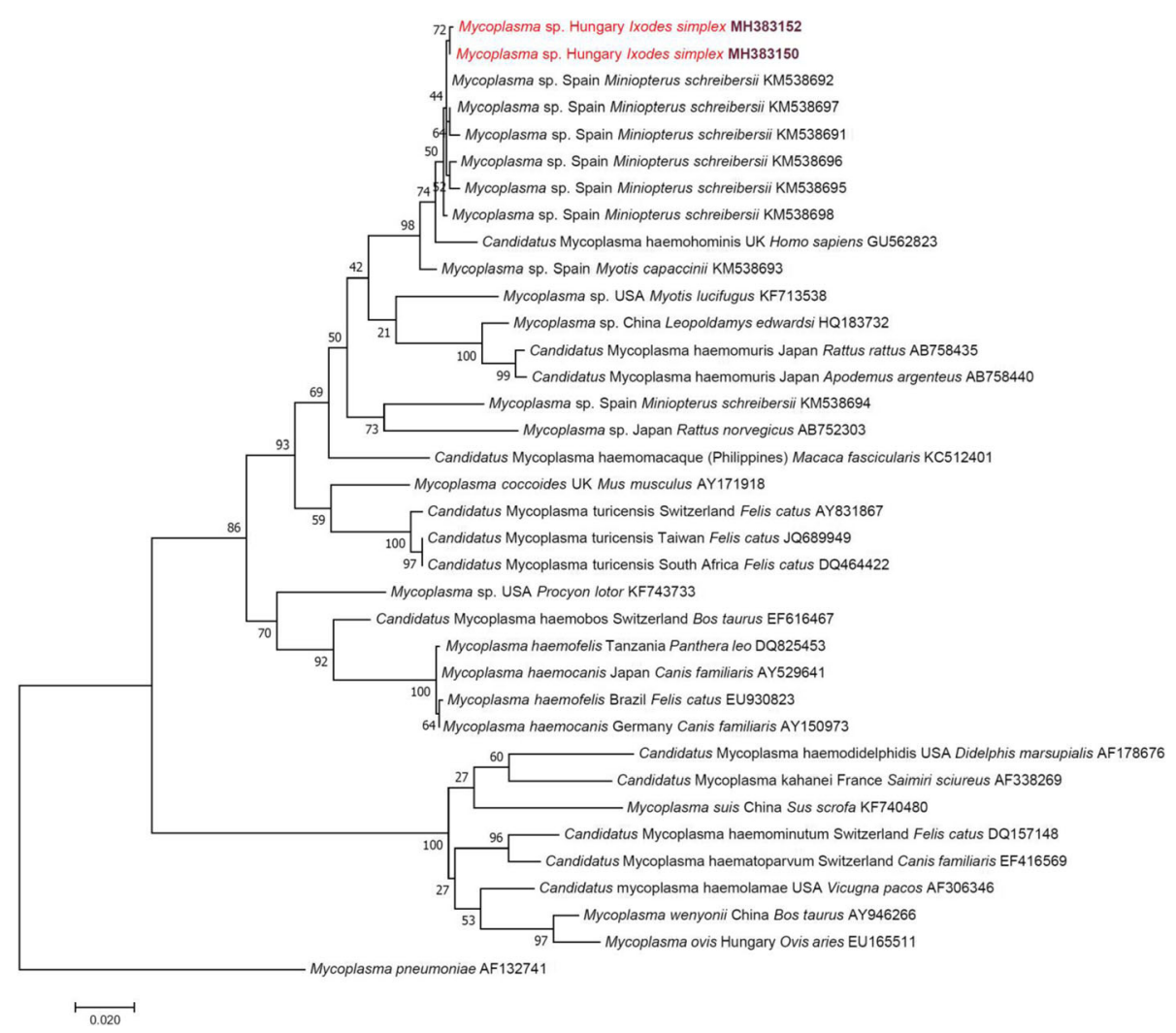

Fig. 2 Maximum-likelihood tree of haemotropic Mycoplasma spp. based on the 16S rRNA gene. Sequences from this study are highlighted with red color and bold accession numbers. After the country name, the isolation source is indicated with genus and species name. Branch lengths represent the number of substitutions per site inferred according to the scale shown

phylogenetically close to “ $\mathrm{Ca}$. M. haemohominis", are reported here for the first time from central Europe and from any bat tick.

\section{Additional files}

Additional file 1: Table S1. Technical data for real-time PCRs used for screening. (DOCX $18 \mathrm{~kb}$ )

Additional file 2: Table S2. Technical data for conventional PCRs used for sequencing. (DOCX $21 \mathrm{~kb}$ )

Additional file 3: Text S1. Methods. (DOCX $20 \mathrm{~kb}$ )

\section{Abbreviations}

Ct: Threshold cycle; ftsZ: Cell division protein; gltA: Citrate synthase; ITS: 16S$23 \mathrm{~S}$ rRNA intergenic spacer region; OmpA: Outer membrane protein-A

\section{Acknowledgements}

Part of the molecular work was performed using the logistics of the Center for Clinical Studies, Vetsuisse Faculty, Zurich, Switzerland. The authors thank the Wildlife Recovery Center Valpredina (Italy) for their collaboration.

\section{Funding}

Molecular work in Hungary was supported by NKFIH 115854. This research was also supported by the 12190-4/2017/FEKUTSTRAT grant of the Hungarian Ministry of Human Capacities. ADS was supported by the János Bolyai Research Scholarship of the Hungarian Academy of Science.

\section{Availability of data and materials}

The sequences obtained and/or analyzed during the present study are deposited in the GenBank database under the accession numbers MH383138-MH383152, MH544201-MH544204 and MH578453. All other relevant data are included in the article.

\section{Authors' contributions}

SH designed the Hungarian part of the study, participated in DNA extraction, supervised molecular phylogenetic analyses and wrote the manuscript. ADS, $T G, P E, Y W, V T T, D K, S A B, A C, A H$ and SE provided important samples and contributed to the study design and the manuscript. KS extracted most of the DNA. MLM, KMS, MG, NT and JK performed molecular and phylogenetic analyses. RHL designed the Swiss part of the study and significantly contributed to the manuscript. All authors read and approved the final manuscript.

\section{Ethics approval}

Permissions for bat capture were provided by the National Inspectorate for Environment and Nature in Hungary (no. 14/2138-7/2011), the Vietnam Administration of Forestry of the Vietnamese Ministry of Agriculture and Rural Development (no. 1206/TCLN-BTTN), the School of Medicine at Shihezi University in China (no. AECSU2015-01), the Underground Heritage Commission in Romania (no. 305/2015), the Kenya Wildlife Service (no. KWS/BRM/5001) and the Secretary of the Environment and Natural Resources in Mexico (no. SEMARNAT-08-049). Permission for bat capture was not needed in Italy, where six bat ticks were collected from bats rescued and hospitalized at the Wildlife Recovery Center. Permissions for bat hospitalization at the Wildlife Recovery Center in Italy were authorized with D.G.R. n. 5485 of 13.07.2001. The bat banding license numbers are TMF-14/32/2010 (DK), 59/2003 (PE), TMF-493/3/2005 (TG), TMF-513/1/2004 (SAB) and 305/2015 (ADS). Bats were released after removal of ticks. 


\section{Consent for publication}

Not applicable.

\section{Competing interests}

The authors declare that they have no competing interests.

\section{Publisher's Note}

Springer Nature remains neutral with regard to jurisdictional claims in published maps and institutional affiliations.

\section{Author details}

'Department of Parasitology and Zoology, University of Veterinary Medicine, Budapest, Hungary. ${ }^{2}$ Clinical Laboratory, Department of Clinical Diagnostics and Services, and Center for Clinical Studies, Vetsuisse Faculty, University of Zurich, Zurich, Switzerland. ${ }^{3}$ Department of Parasitology and Parasitic Diseases, University of Agricultural Sciences and Veterinary Medicine, Cluj-Napoca, Romania. ${ }^{4}$ Department of Zoology, Hungarian Natural History Museum, Budapest, Hungary. ${ }^{5}$ Department of Zoology, Eszterházy Károly University, Eger, Hungary. ${ }^{6}$ Department of Pathogenic Biology, School of Medicine, Shihezi University, Shihezi, China. ${ }^{7}$ Institute of Ecology and Biological Resources, Vietnam Academy of Science and Technology, Hanoi, Vietnam. ${ }^{8}$ Hungarian Biodiversity Society, Budapest, Hungary. ${ }^{9}$ Directorate, Aggtelek National Park, Jósvafó, Hungary. ${ }^{10}$ Institute for Veterinary Medical Research, Centre for Agricultural Research, Hungarian Academy of Sciences, Budapest, Hungary. ${ }^{11}$ Plant Protection Institute, Centre for Agricultural Research, Hungarian Academy of Sciences, Budapest, Hungary. ${ }^{12}$ Department of Biodiversity, School of Molecular and Life Sciences, Faculty of Science and Agriculture, University of Limpopo, Sovenga, South Africa. ${ }^{13}$ Department of Biosciences and Pediatric Clinical Research Center "Romeo and Enrica Invernizzi", University of Milan, Milan, Italy.

Received: 27 July 2018 Accepted: 7 January 2019

Published online: 22 January 2019

\section{References}

1. Hutterer R, Ivanova T, Meyer-Cords C, Rodrigues L. Bat migrations in Europe. A review of banding data and literature. Naturschutz und Biologische Viefalt 28. Bonn: Federal Agency for Nature Conservation; 2005. p. 162.

2. Brook CE, Dobson AP. Bats as 'special' reservoirs for emerging zoonotic pathogens. Trends Microbiol. 2015;23:172-80.

3. Piksa K, Nowak-Chmura M, Siuda K. First case of human infestation by the tick Ixodes vespertilionis (Acari: Ixodidae). Int J Acarol. 2013;38:1-2.

4. Jaenson TG, Tälleklint L, Lundqvist L, Olsen B, Chirico J, Mejlon H. Geographical distribution, host associations, and vector roles of ticks (Acari: Ixodidae, Argasidae) in Sweden. J Med Entomol. 1994;31:240-56.

5. Socolovschi C, Kernif T, Raoult D, Parola P. Borrelia, Rickettsia, and Ehrlichia species in bat ticks, France, 2010. Emerg Infect Dis. 2012;18:1966-75.

6. LV J, Fernández de Marco MDM, Goharriz H, Phipps LP, McElhinney LM, Hernández-Triana LM, et al. Detection of tick-borne bacteria and babesia with zoonotic potential in Argas (Carios) vespertilionis (Latreille, 1802) ticks from British bats. Sci Rep. 2018;8:1865.

7. Piksa K, Stańczak J, Biernat B, Górz A, Nowak-Chmura M, Siuda K. Detection of Borrelia burgdorferi sensu lato and spotted fever group rickettsiae in hard ticks (Acari, Ixodidae) parasitizing bats in Poland. Parasitol Res. 2016;115: 1727-31.

8. Hornok S, Szőke K, Kováts D, Estók P, Görföl T, Boldogh SA, et al. DNA of piroplasms of ruminants and dogs in ixodid bat ticks. PLoS One. 2016;11: e0167735.

9. Hornok S, Szőke K, Görföl T, Földvári G, Tu VT, Takács N, et al. Molecular investigations of the bat tick Argas vespertilionis (Ixodida: Argasidae) and Babesia vesperuginis (Apicomplexa: Piroplasmida) reflect "bat connection" between central Europe and central Asia. Exp Appl Acarol. 2017;72:69-77.

10. Hornok S, Kovács R, Meli ML, Kontschán J, Gönczi E, Gyuranecz M, et al. First detection of bartonellae in a broad range of bat ectoparasites. Vet Microbiol. 2012;159:541-3.

11. Hornok S, Szőke K, Estók P, Krawczyk A, Haarsma AJ, Kováts D, et al. Assessing bat droppings and predatory bird pellets for vector-borne bacteria: molecular evidence of bat-associated Neorickettsia sp. in Europe. Antonie Van Leeuwenhoek. 2018;111:1707-17.

12. Sekeyová Z, Mediannikov O, Roux V, Subramanian G, Spitalská E, Kristofík J, et al. Identification of Rickettsia africae and Wolbachia sp. in Ceratophyllus garei fleas from passerine birds migrated from Africa. Vector Borne Zoonotic Dis. 2012:12:539-43.

13. Roux V, Rydkina E, Eremeeva M, Raoult D. Citrate synthase gene comparison, a new tool for phylogenetic analysis, and its application for the rickettsiae. Int J Syst Bacteriol. 1997;47:252-61.

14. Acosta ICL, Luz HR, Faccini-Martínez ÁA, Muñoz-Leal S, Cerutti JC, Labruna MB. First molecular detection of Rickettsia sp. strain Atlantic rainforest in Amblyomma ovale ticks from Espírito Santo State, Brazil. Rev Bras Parasitol Vet. 2018:27:420-2.

15. Paddock CD, Allerdice MEJ, Karpathy SE, Nicholson WL, Levin ML, Smith TC, et al. Unique strain of Rickettsia parkeri associated with the hard tick Dermacentor parumapertus Neumann in the western United States. Appl Environ Microbiol. 2017;83:e03463-16.

16. Portillo A, de Sousa R, Santibáñez S, Duarte A, Edouard S, Fonseca IP, et al. Guidelines for the detection of Rickettsia spp. Vector Borne Zoonotic Dis. 2017;17:23-32.

17. Duh D, Punda-Polic V, Avsic-Zupanc T, Bouyer D, Walker DH, Popov VL, et al Rickettsia hoogstraalii sp. nov., isolated from hard- and soft-bodied ticks. Int J Syst Evol Microbiol. 2010;60:977-84.

18. Milhano N, Palma M, Marcili A, Núncio MS, de Carvalho IL, de Sousa R. Rickettsia lusitaniae sp. nov. isolated from the soft tick Ornithodoros erraticus (Acarina: Argasidae). Comp Immunol Microbiol Infect Dis. 2014;37:189-93.

19. Sánchez-Montes S, Guzmán-Cornejo C, Martínez-Nájera Y, Becker I, Venzal JM, Labruna MB. Rickettsia lusitaniae associated with Ornithodoros yumatensis (Acari: Argasidae) from two caves in Yucatan, Mexico. Ticks Tick Borne Dis. 2016:7:1097-101.

20. Urushadze L, Bai Y, Osikowicz L, McKee C, Sidamonidze K, Putkaradze D, et al. Prevalence, diversity, and host associations of Bartonella strains in bats from Georgia (Caucasus). PLoS Negl Trop Dis. 2017;11:e0005428.

21. McKee CD, Kosoy MY, Bai Y, Osikowicz LM, Franka R, Gilbert AT, et al. Diversity and phylogenetic relationships among Bartonella strains from Thai bats. PLoS One. 2017;12:e0181696.

22. Lilley TM, Veikkolainen $\mathrm{V}$, Pulliainen AT. Molecular detection of Candidatus Bartonella hemsundetiensis in bats. Vector Borne Zoonotic Dis. 2015;15:706-8.

23. Millán J, López-Roig M, Delicado V, Serra-Cobo J, Esperón F. Widespread infection with hemotropic mycoplasmas in bats in Spain, including a hemoplasma closely related to "Candidatus Mycoplasma hemohominis". Comp Immunol Microbiol Infect Dis. 2015;39:9-12.

24. Neimark $H$, Johansson KE, Rikihisa Y, Tully JG. Proposal to transfer some members of the genera Haemobartonella and Eperythrozoon to the genus Mycoplasma with descriptions of "Candidatus Mycoplasma haemofelis", "Candidatus Mycoplasma haemomuris", "Candidatus Mycoplasma haemosuis" and "Candidatus Mycoplasma wenyonii". Int J Syst Evol Microbiol. 2001;51:891-9.

25. Hornok S. Ixodes simplex Neumann, 1906. In: Estrada-Peña A, Mihalca AD, Petney TN, editors. Ticks of Europe and North Africa: A Guide to Species Identification. Cham: Springer International Publishing. 2017. p. 103-7.
Ready to submit your research? Choose BMC and benefit from:

- fast, convenient online submission

- thorough peer review by experienced researchers in your field

- rapid publication on acceptance

- support for research data, including large and complex data types

- gold Open Access which fosters wider collaboration and increased citations

- maximum visibility for your research: over $100 \mathrm{M}$ website views per year

At $\mathrm{BMC}$, research is always in progress.

Learn more biomedcentral.com/submission 